УДК 551.4+911.9

DOI: $10.18101 / 2542-0623-2020-2-64-88$

\title{
ОПАСНЫЕ ГЕОМОРФОЛОГИЧЕСКИЕ ПРОЦЕССЫ НА ЛОКАЛЬНОМ ПОЛИГОНЕ БАЙКАЛЬСКОЙ ПРИРОДНОЙ ТЕРРИТОРИИ
}

\section{С. Б. Кузьмин}

\section{(c) Кузьмин Сергей Борисович}

доктор географических наук, ведущий научный сотрудник, Институт географии им. В. Б. Сочавы СО РАН, Россия, 664033, г. Иркутск, ул. Улан-Баторская, 1 kuzmin@irigs.irk.ru

\begin{abstract}
Аннотация. Рассмотрены опасные геоморфологические процессы на локальном полигоне Кулура, который расположен в Приольхонье, Западное Прибайкалье, на Байкальской природной территории. В связи с жестким природоохранным статусом региона основным видом хозяйственной деятельности здесь является туризм. Рассмотрены геолого-геоморфологические условия, способствующие развитию этого вида хозяйства. Определена степень антропогенной нарушенности полигона. Выделены основные критерии и проведена оценка риска природопользования в результате активизации опасных геоморфологических процессов. Предложены мероприятия по снижению риска.
\end{abstract}

Ключевые слова: опасные геоморфологические процессы; риск природопользования; Приольхонье; Байкальская природная территория.

\section{Для цитирования}

Кузьмин С. Б. Опасные геоморфологические процессы на локальном полигоне Байкальской природной территории // Природа Внутренней Азии. Nature of Inner Asia. 2020. № 2(15). C. 64-88. DOI: 10.18101/2542-0623-2020-2-64-88

\section{Введение}

В последние годы вопросам изучения опасных геоморфологических процессов для оценки геоэкологического риска и обеспечения экологической безопасности на рекреационных территориях уделяется большое внимание [Фаддеев, 2008; Антипцева, Думит, 2009; Минаев, Фаддеев, 2009; Бредихин, 2010; Макаренко, 2015; и др.]. Особенно это характерно для охраняемых природных территорий. В Российской Федерации в пределах Внутренней Азии выделяется Байкальская природная территория. Природный потенциал оз. Байкал и окружающих ландшафтов имеет международное значение и является достоянием всего человечества. Наиболее ярко природные особенности охраняемых ландшафтов Байкала проявляются на локальных полигонах. Одновременно на них проживает местное население, которое ведет свое подсобное хозяйство, а также развита туристическая отрасль экономики. Природные процессы и антропогенная деятельность оказывают друг на друга активное влияние, которое часто является весьма негативным, создает опасные ситуации. Регулированию природно-антропогенных взаимоотношений, особенно на муниципальном уровне, на Байкальской природной 
C. Б. Кузьмин. Опасные геоморфологические процессы на локальном полигоне Байкальской природной территории

территории уделяется большое внимание на всех уровнях администрирования. Рассмотрим этот вопрос на примере локального полигона Кулура, расположенного на побережье залива Мухор в Приольхонье, Западное Прибайкалье (рис. 1).

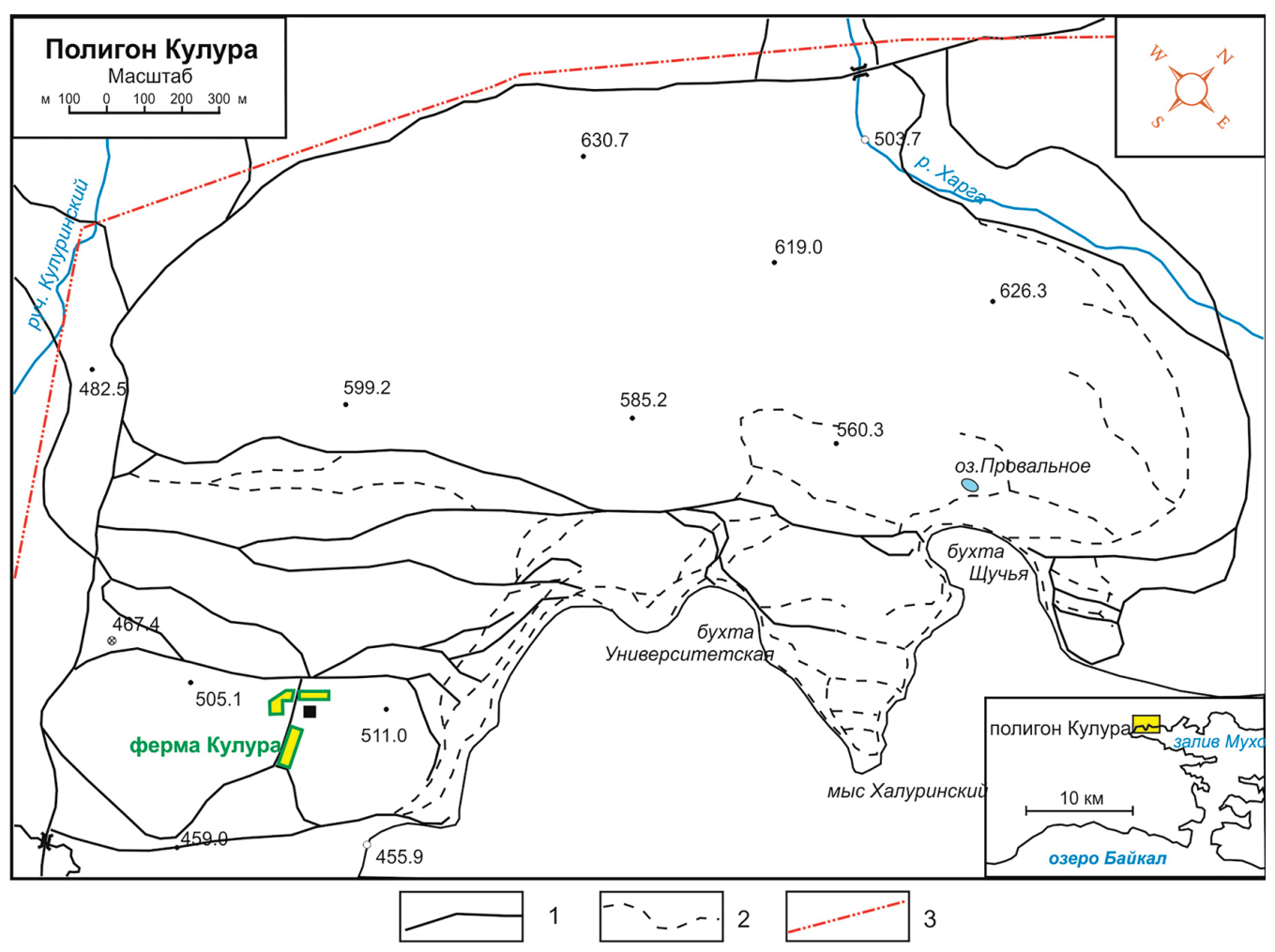

Рис. 1. Полигон Кулура: 1 - автодороги, 2 - тропы, 3 - линия электропередачи

Площадь полигона составляет около 5 км², что позволяет проводить детальные исследования. Он имеет серповидную в плане форму, слегка вытянут с юго-запада на северо-восток. Естественной границей полигона на юге и юго-востоке является береговая линия залива Мухор и долина реки Кучелга. С запада и севера полигон ограничивает улучшенная грунтовая дорога районного значения Еланцы - Зама, проходящая по продольной седловине между двумя гребнями. С северо-востока и востока полигон ограничивает долина реки Харга. Расстояние от полигона до ближайшего населенного пункта - поселка Шара-Тагот (Черноруд) - составляет 2 км, до поселка Сарма - 8 км, до поселка Сахюрта (МРС) - 11 км. По периметру и внутри полигона проходят дороги, доступные для легкового транспорта, пешеходные тропы.

\section{Характеристика природы и хозяйства}

На полигоне Кулура можно встретить многие типичные для всего Приольхонья ландшафты. Он обладает природными ресурсами, достаточными для развития многих видов туризма (летнего и зимнего): пешего, конного, альпинизма, спелеотуризма, познавательного, эколого-образовательного, водного, спортивного рыболовства, аэро- и гелеотерапии, буерного, конькобежного, лыжного и санного туризма, авто- и мототуризма и т. д. 
На полигоне развиты все виды хозяйственной деятельности, характерные в целом для Приольхонья. Сельское хозяйство ведется на ферме Кулура (сенокосы, пастбища, огороды). Рекреация представлена неорганизованным и частично организованным туризмом на побережье залива Мухор. В последние годы участились выезды на побережье организованных детских лагерей. С 2001 г. АО «Вид» арендовало часть земель и в 2004-2005 гг. построило туристическую базу в бухте Университетская. Традиционные промыслы на полигоне представлены рыбалкой и сбором лекарственных трав.

На полигоне Кулура можно обнаружить участки очень высокой антропогенной нарушенности (вдольбереговая полоса залива, освоенная туристами). Одновременно внутренние районы полигона слабо затронуты человеком, могут служить эталоном ненарушенных (фоновых) земель. Большую часть территории полигона составляют ландшафты, испытавшие на себе в разные годы незначительное (слабое) антропогенное воздействие.

В геологическом отношении территория полигона сложена главным образом Чернорудской свитой докембрия. Поверхностные кристаллические горные породы представлены биотитовыми, роговообманковыми, роговообманково-биотитовыми и гранатовыми гнейсами. В толщах гнейсов имеются прослои кристаллических известняков, кварцитов, мраморов и амфиболитов. Встречаются инъекционные гнейсы (рис. 2).

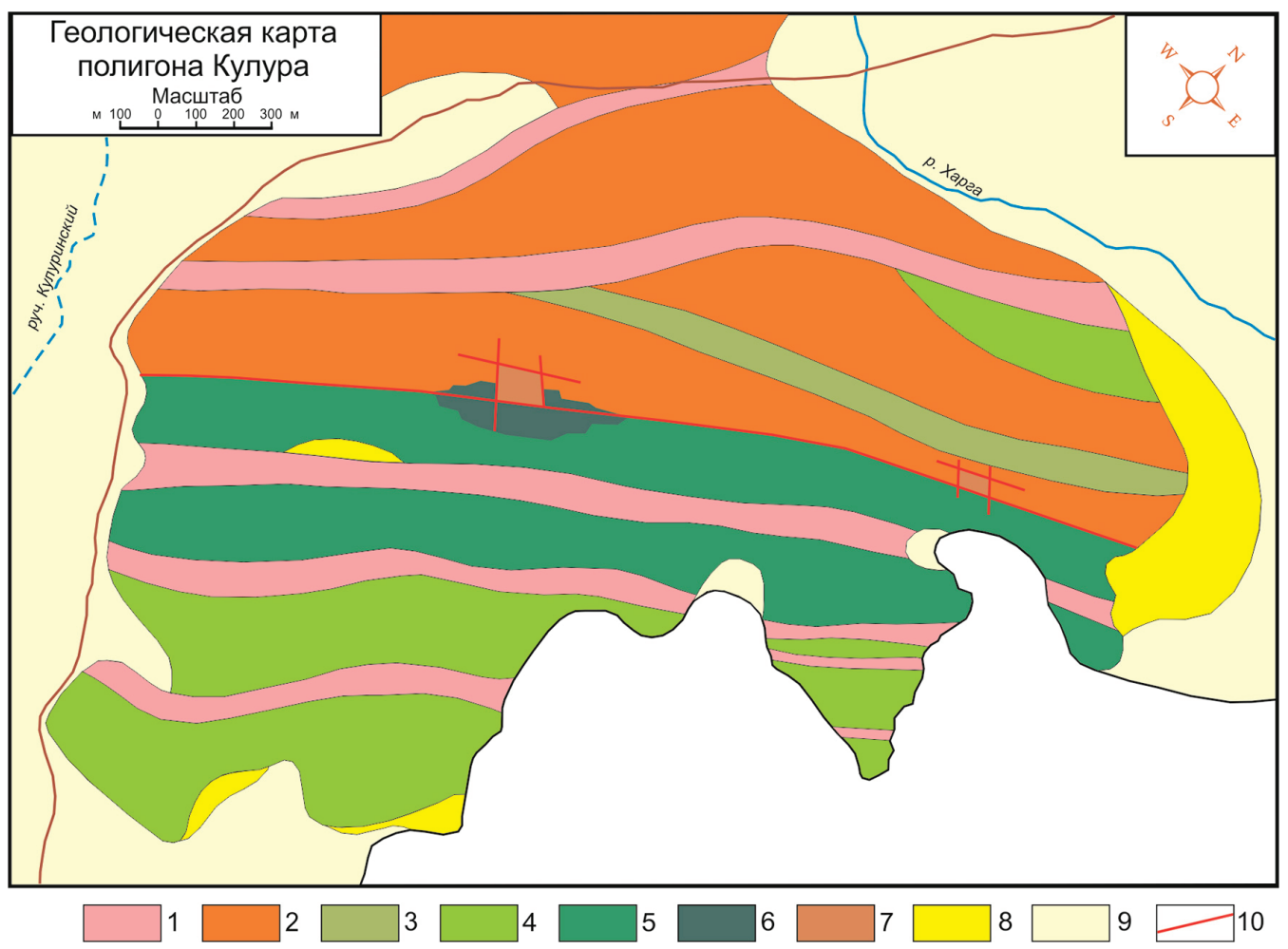

Puc. 2. Геологическая карта полигона Кулура. 1 - мраморы, 2 - гранито-гнейсы, 3 - биотитовые гнейсы, 4 - биотит-амфиболовые гнейсы, 5 - амфиболовые гнейсы, 6 - амфиболиты, 7 - пегматиты, 8 - верхнеплейстоценовые рыхлые отложения, 9 современные и голоценовые рыхлые отложения, 10 - разломы 
Прослои гнейсов и карбонатных пород не испытывают нормального залегания, а расположены субвертикально - результат тектонических движений. Эта структурная позиция формирует в рельефе серии параллельных гребней и гряд, сложенных более устойчивыми к денудации гнейсами, и разделяющих их параллельных межгрядовых понижений, основу которых составляют карбонатные, менее устойчивые к денудации породы - известняки и мраморы.

Полигон входит в зону Приморского разлома. Неотектонические движения здесь используют для своей реализации ослабленные контакты между слоями гнейсов и мраморов, усиливая контрастность рельефа. Сформировавшиеся в прошлые геологические эпохи зоны милонитов, бластомилонитов, катаклазитов также используются современной тектоникой. По ним проходят тектонические разрывы и закладываются отрицательные формы рельефа. Наиболее отчетливо это можно проследить в обнажениях береговых абразионных уступов.

На полигоне представлены типичные для Приольхонья формы рельефа (рис. 3). На дне долин рек Харга и Кучелга распространены неоплейстоценовые рыхлые отложения. Поймы сложены голоценовыми аллювиальными осадками. Пойменная фация аллювия перерабатывается процессами заболачивания и криогенеза, за счет чего формируется песчано-галечный с примесями глин, илов и алевролитов плащ рыхлых осадков. В ландшафте на нем образуются заливные луга, местами - кочкарно-западинные лугово-болотные фации. Русловая фация аллювия представлена галечно-гравийным и галечно-валунным материалом. Под северным склоном хребта Северо-Восточный в русле р. Харги ежегодно формируются наледи. Поздний неоплейстоцен - голоценовые рыхлые осадки - представлен в невысоких террасах рек Харга и Кучелга. Терраса р. Харги хорошо прослеживается на правом берегу реки вблизи ее впадения в залив Мухор. Ее высота достигает 1,5-2,0 м, наибольшая ширина - 150 м. Через 500 м вверх по долине реки терраса практически выклинивается. Осадки, слагающие террасу, представлены песчаным и галечно-гравийным материалом, который в местах древних русел подстилается валунно-галечными отложениями. Древний аллювий использовался архаичными цивилизациями для строительства культовых сооружений. Из экзогенных геологических процессов развиты гравитационные, эрозионные, денудационные склоновые, абразионные, карстово-суффозионные, заболачивание, дефляция, мерзлотные. Многие формы рельефа имеют смешанный генезис: гравитационносуффозионный, абразионно-гравитационный, дефляционно-абразионный.

Гравитационные процессы развиты на крутых склонах и уступах, выработанных вдоль плоскостей разломов, структурных контактов горных пород, на абразионных клифах побережья. Эрозионные процессы преобладают на дне долин рек Кучелга и Харга и суходольных логах, которые, спускаясь к побережью, расширяются и превращаются в бухты. Процессы плоскостной денудации развиты на пологих склонах и склонах средней крутизны, где, кроме смещения плаща рыхлых делювиальных осадков, приводят к формированию деллей и ложбин стока. Абразионные процессы развиты вдоль мысов и полуостровов, образуют обрывистые отвесные берега, гроты, клифы и бенчи. В бухтах вдоль побережий в спокойных гидродинамических условиях происходит аккумуляция рыхлых озерных осадков 
в виде тонкодисперсного ила и алевритовых разностей; в мелких бухтах на мысах и вдоль скалистых берегов формируются узкие песчано-галечные защебненные делювием пляжи, главным образом фрагментарные, но иногда вытягивающиеся на 100-150 м. Карстово-суффозионные процессы развиты в породах известкового состава (мраморы), но большого самостоятельного значения не имеют и приводят к формированию значимых форм рельефа в совокупности с другими агентами морфогенеза. Это же относится к заболачиванию, седиментации и криогенным процессам в поймах рек и на побережье бухт, которые в совокупности образуют своеобразные формы микрорельефа (рис. 4).

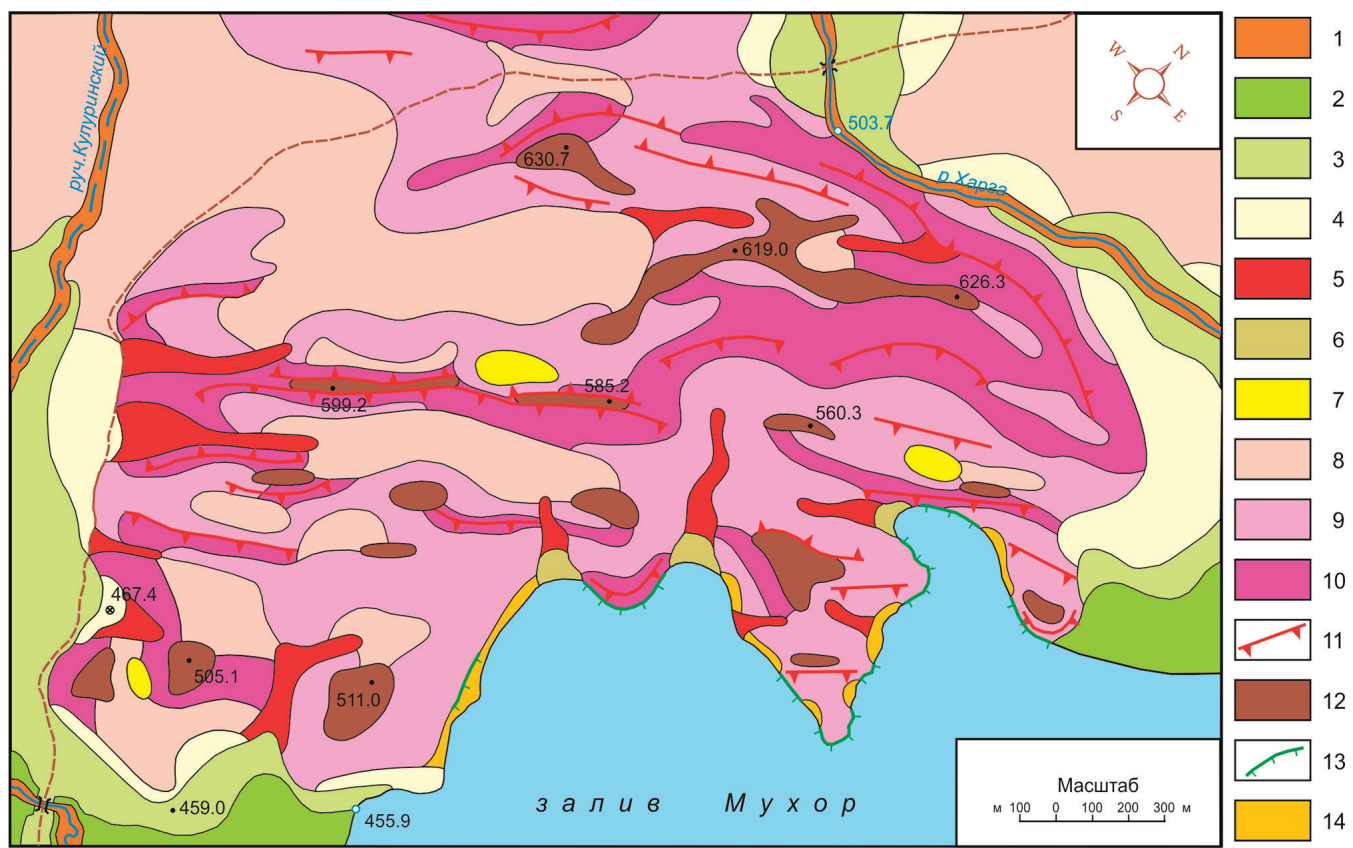

Puc. 3. Геоморфологическая карта полигона Кулура. Пойменно-долинный комплекс: 1 - русла рек с развитой глубинной и боковой эрозией; 2 - низкая пойма с процессами заболачивания, торфообразования, термокарста, криогидротационного выветривания; 3 высокая пойма с процессами торфообразования, термокарста, криогидротационного выветривания, криогенной десерпции, формирования дорог и троп; 4 - террасы; 5 - лога, распадки и долины временных водотоков с глубинной и боковой эрозией; 6 - устьевые части распадков с процессами заболачивания; 7 - замкнутые бессточные котловины с процессами очаговой аккумуляции. Склоново-водораздельный комплекс: 8 - пологие склоны $\left(3-7^{0}\right)$ с процессами плоскостного смыва, овражной эрозии, криогенной десерпции; 9 - склоны средней крутизны $\left(7-15^{0}\right)$ с процессами струйчатого и плоскостного смыва, дефлюкции, криогидротационного выветривания; 10 - крутые склоны $\left(15-30^{\circ}\right)$ с осыпями и обвалами, процессами морозного выветривания, криогенного сплывания, струйчатого смыва, карста; 11 - уступы (более 300) с осыпями и обвалами, тектоническим крипом, морозным выветриванием, дефляцией карстом; 12 - водораздельные гривы, гребни и увалы с морозным выветриванием и десерпцией. Прибрежно-озерный комплекс: 13 - абразионные уступы с обваливанием и осыпанием, денудирующей деятельностью волн, дефляцией; 14 - пляжи с аккумулятивной деятельностью волн, осыпанием, дефляцией 
С. Б. Кузьмин. Опасные геоморфологические процессы на локальном полигоне Байкальской природной территории

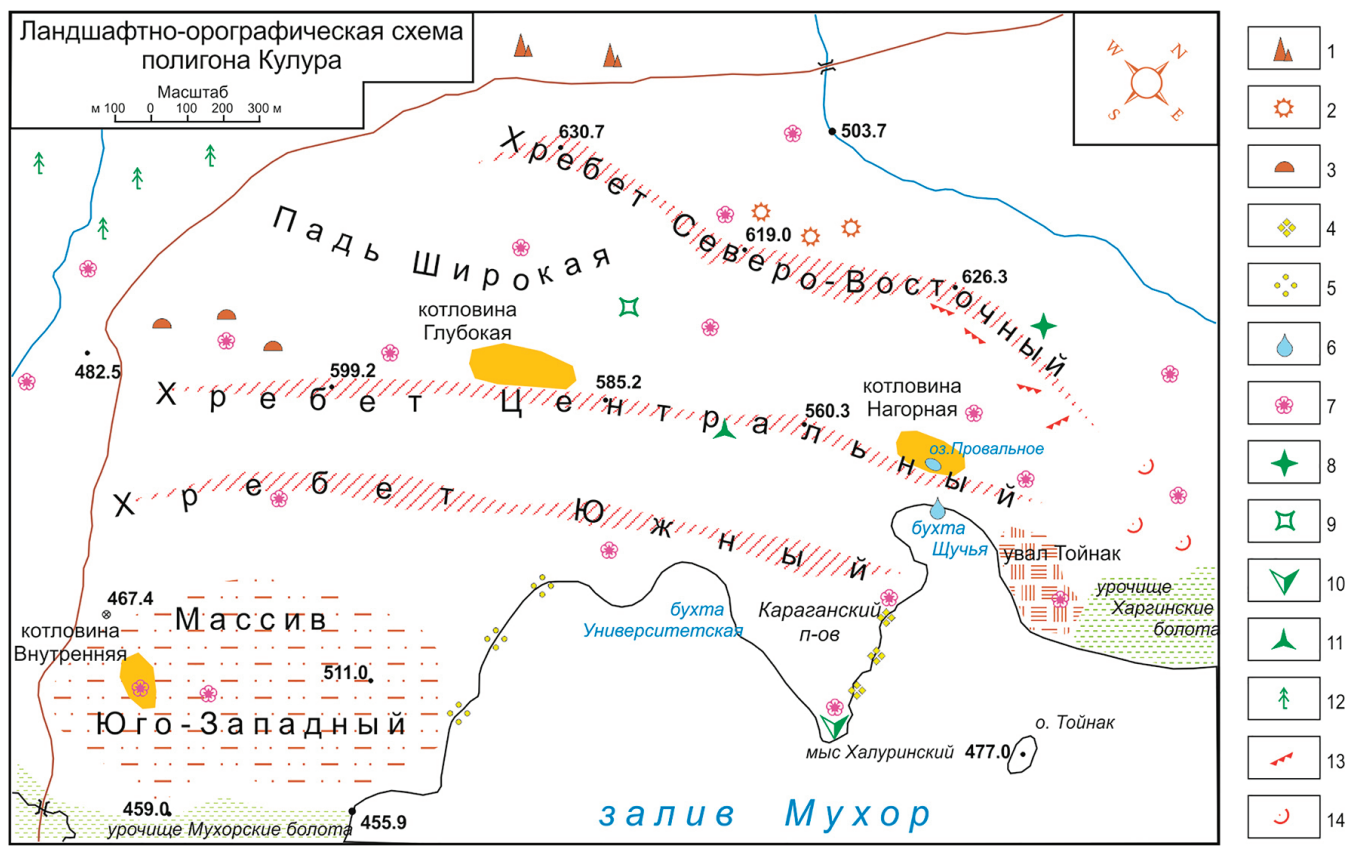

Puc. 4. Ландшафтно-орографическая схема полигона Кулура. 1 - скалы, 2 - нагорные террасы, 3 - выровненные поверхности. Пляжи: 4 - галечные, 5 - песчаные, 6 - родники, 7 - места сбора дикоросов. Ландшафтные памятники: 8 - ущелье "Ласточкин провал”, 9 - урочище “Седло", 10 - урочище "На семи ветрах", 11 - урочище "Темное”, 12 - урочище "Кулуринские лески”. Историко-этнографические памятники курумчинской культуры: 13 - развалины оборонительных сооружений, 14 - развалины культовообрядовых сооружений

Для северо-западного побережья залива Мухор, где расположен полигон, характерно сочетание ландшафтов подтайги, ксерофитных остепненных лесов, остепненных лугов и степи. Ландшафты подтайги развиты на северных приводораздельных склонах и представлены редколесными лиственничными лесами (с сосной) со слаборазвитым подростом и подлеском из рододендрона даурского на дерновых лесных слаборазвитых маломощных почвах. В нижних частях склонов со сменой экспозиции и выполаживанием поверхности подтайга резко переходит в остепненные светлохвойные леса и степь. Ландшафты светлохвойных лесов занимают пологие склоны, лощины и пади, представлены остепененными редкостойными лиственничниками в сочетании с лиственничным редколесьем на водоразделах и крутых склонах на примитивно-щебнистых, дерновых лесных и дерновых остепненных почвах и участками остепненных лугов на горных степных и горных черноземовидных почвах. Степные ландшафты занимают основную площадь полигона. Для них характерны сообщества горных и настоящих степей на горных степных почвах, а также петрофитные варианты настоящих степей на литогенных почвах. Фрагменты кустарниковых зарослей настоящих степей приурочены к крутым и каменистым береговым склонам. Кустарниковые и луговые ландшафты распространены узкими полосами вдоль русел рек Харга и Кучелга.

В результате полевого обследования выделены следующие ландшафты: 1) грядовые светлохвойные мохово-разнотравные редколесья в комплексе 
с низкоразнотравными редколесными остепненными лиственничниками на примитивно-щебнистых и дерновых литогенных почвах с выходами скал; 2) грядовые остепненные лиственничные редколесья в сочетании с горными степными сообществами на горно-степных почвах с выходами скал; 3) выположенных поверхностей редколесные светлохвойные разнотравно-моховые леса в комплексе с редколесными разнотравными лиственничниками на дерновых лесных слаборазвитых почвах в сочетании со злаково-низкоразнотравными степями на дерновых степных и горно-степных почвах; 4) крутосклоновые мелкодерновинно-злаковые и низкоразнотравно-полынные степи на примитивно-щебнистых и горно-степных почвах с выходами скал; 5) склоновые редколесные светлохвойные мохово-разнотравные леса в комплексе с остепненными лиственничниками на дерновых лесных слаборазвитых и дерновых степных почвах; 6) склоновые остепненные лиственничные редколесья на примитивно-щебнистых почвах в сочетании с мелкодерновиннозлаковыми степями на горно-степных примитивных, горно-степных бескарбонатных и горных черноземовидных почвах; 7) пологих склонов злаково-низкоразнотравные степи на горно-степных карбонатных почвах; 8) склоновые лиственничные остепненные редколесья на дерновых степных и горно-степных почвах с выходами скал; 9) склоновые мелкодерновинно-злаковые и низкоразнотравные степи на примитивно-щебнистых и горно-степных почвах; 10) речных долин луговоболотные кустарниковые на аллювиальных луговых глеевых и лугово-болотных торфянисто- и перегнойно-глеевых почвах; 11) низких террас и пляжей с осоковоразнотравными лугами на луговых, лугово-болотных глееватых и глеевых почвах; 12) котловинные склоновые мелкодерновинно-злаковые и низкоразнотравнополынные степи на слаборазвитых песчаных и примитивно-щебнистых почвах; 13) котловинные мезофитных лугов на лугово-болотных перегнойно-глеевых почвах; 14) крутосклоновые кустарниковые на примитивно-щебнистых почвах с выходами скал; 15) склоновые лиственничные остепненные редколесья на дерновых слаборазвитых и горно-степных почвах с выходами скал.

\section{Рельеф полигона как ресурс для развития туризма}

Среди наиболее пригодных для развития туризма форм рельефа на полигоне выделены: 1) уступы (эскарпы); 2) останцовые вершины и водораздельные гребни; 3) котловины; 4) седловины; 5) пади и лога; 6) террасы и пойма; 7) бухты и пляжи; 8) гребнисто-западинные системы (рис. 5).

Для каждой формы рельефа подобраны эколого-геоморфологические критерии рекреационно-туристической значимости. Они делятся на две группы: 1) морфометрические; 2) эстетические. Морфометрические критерии характеризуют показатели рельефа, которые способствуют их техническому использованию в рекреационно-туристических целях: геометрические характеристики (длина, ширина, площадь), экспозиционное положение, углы наклона и структура элементарных геоморфологических поверхностей, дальность и периметр обзора, соотношение с соседними формами рельефа. Эстетические критерии обеспечивают формирование соответствующих психических образов в сознании человека, которые побуждают его к отдыху среди данных форм рельефа. Эти критерии субъективны, зависят от личных качеств людей, поэтому выделены в наиболее общем виде. 


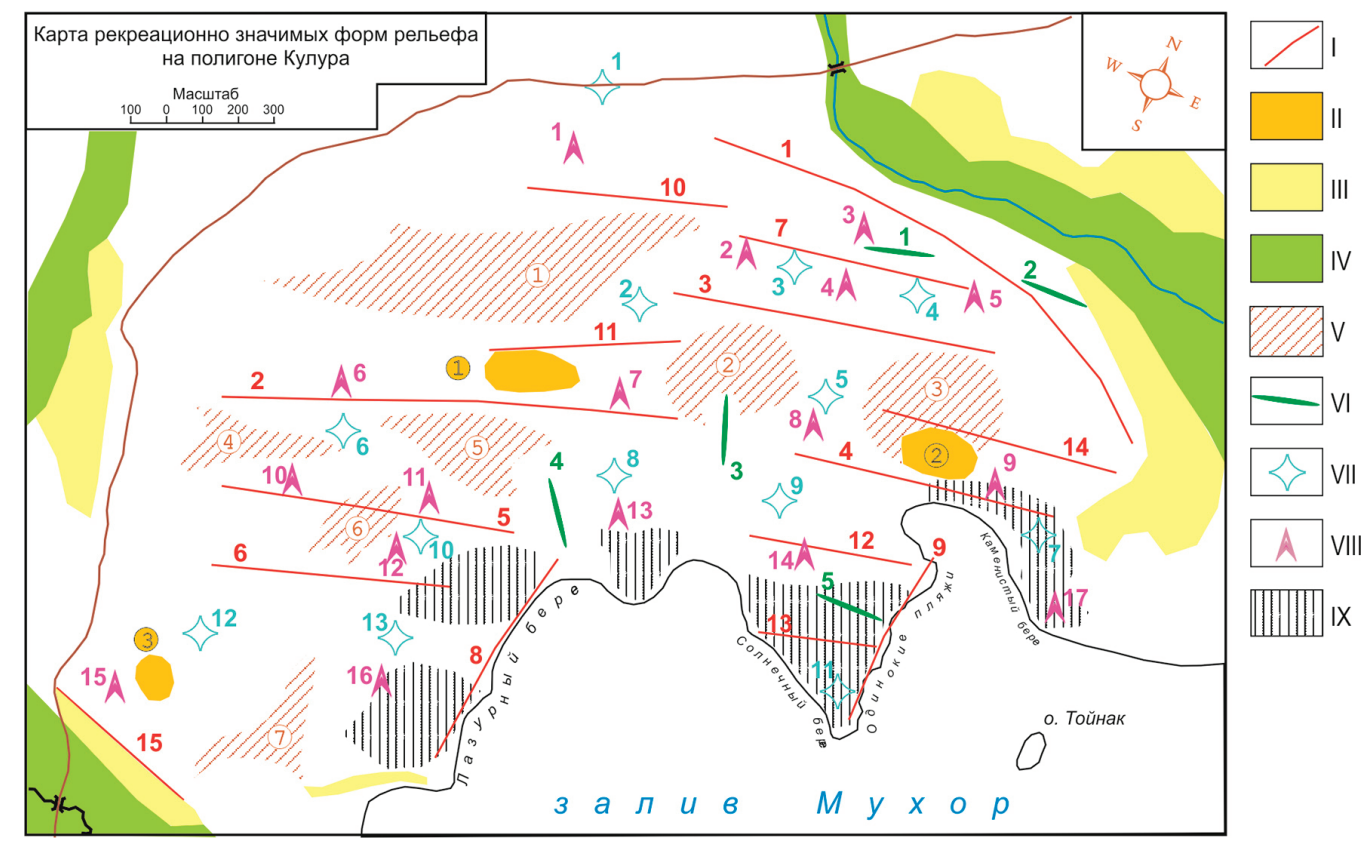

Puc. 5. Формы рельефа на полигоне Кулура, значимые для развития туризма. I - эскарпы: 1 - Харгинский, 2 - Центральный, 3 - Нагорный, 4 - Скалистый, 5 - Безлесный, 6 - Живописный, 7 - Вершинный, 8 - Прибрежный, 9 - Темный, 10 - Сосновый, 11 - Угрюмый, 12 - Скрытый, 13 - Красный, 14 - Надозерный, 15 - Пологий. II котловины: 1 - Нагорная, 2 - Глубокая, 3 - Внутренняя. III - террасы. IV - пойменнорусловые комплексы рельефа. V - пади: 1 - Широкая, 2 - Амфитеатр-1, 3 - Амфитеатр-2, 4 - Приразломная, 5 - Лесистая, 6 - Солнечная, 7 - Фермерская. VI - лога: 1 - Обрывистый, 2 - Ласточкин провал, 3 - Ущелье, 4 - Крутой, 5 - Степной. VII седловины. VIII - вершины. IX - гребнисто-западинные системы

Уступы и сформированные ими эскарпы развиты вдоль локальных и региональных линеаментов (разломов и зон трещиноватости). Наиболее крупный Харгинский эскарп расположен на правом борту р. Харга. Его высота достигает 100-120 м, протяженность - 1500 м. Он заложен по Харгинской субширотной системе линеаментов. Эскарп сформирован практически единым уступом в центральной части. По направлению к флангам он распадается на серию мелких уступов, которые постепенно выполаживаются и переходят в склоны средней крутизны. Активное развитие гравитационных и эрозионных процессов на эскарпе сдерживается растительностью. На северном склоне в условиях достаточного увлажнения произрастает лиственничный лес со значительной примесью сосны (редко - березы). В лесу хорошо развит подлесок и подрост. Менее крупный Центральный эскарп расположен на юго-восточном склоне хребта Центральный. Имея протяженность около 1200 м, он достигает высоты 30-50 м. Северо-восточный его фланг более высокий (до 60 м), но более пологий, представлен серией мелких уступов и соединяющих их склонов средней крутизны. Юго-западный фланг, напротив, более низкий, но значительно более крутой, фактически представляет собой единый уступ высотой до 30 м. Более мелкие уступы характерны для других мест. 
Эскарпы обладают высоким потенциалом для развития туризма. Около $80 \%$ из них имеют юго-восточную или юго-западную экспозицию. Средняя протяженность до 700 м и высота до 30-40 м достаточны для проведения комплексных эколого-рекреационных мероприятий. Разнообразная морфология поверхности от отвесных скалистых стенок и скальных обрывов до слаботеррасированных умеренно крутых склонов с пологими площадками - значительно расширяет список видов отдыха, туризма и характера их сложности. Большинство эскарпов являются физически легко доступными для изучения и рекреации. Имеются, впрочем, и труднодоступные эскарпы, которые наиболее привлекательны для развития альпинизма и пешего туризма повышенной сложности. Около 70\% эскарпов на полигоне обладает высокой пейзажной привлекательностью и эстетической ценностью.

Примечательными элементами рельефа являются останцовые вершины и водораздельные узкие гребни. Они могут использоваться для масштабных наблюдений, оценки ландшафтной и синоптической ситуации, выбора объектов научнопознавательного туризма, изучения горных пород и рельефа. Почти все останцы и гребни являются господствующими на местности вершинами; более половины имеет превышение над уровнем залива Мухор более 100 м (из них три - более 170 м), что больше среднего превышения всей территории полигона (75-80 м). Вершины позволяют наблюдать эстетически значимые элементы ландшафта на значительном удалении. Четыре вершины имеют полную $\left(360^{\circ}\right)$ панораму обзора; около $60 \%$ вершин имеет обзор на $180^{\circ}$. Перспектива обзора $75 \%$ вершин превышает 10 км; три вершины имеют дальность обзора более 30 км. Разнообразная морфология вершин и гребней позволяет варьировать в широких пределах с выбором целей, характера и сложности туристических маршрутов. Половина вершин является легко доступной, имеет высокую пейзажную привлекательность и эстетическую ценность.

Под действием гравитационных и суффозионных процессов формируются провалы и котловины в рельефе. На полигоне располагаются три такие котловины: Глубокая, Нагорная и Внутренняя. Глубокая имеет эллипсовидную в плане форму, вытянута в северо-восточном направлении, ее ширина - 100-120 м, длина 200-250 м, глубина - 35-40 м. Границы котловины контрастные, оформлены крутыми склонами. Северные склоны задернованы, южные представлены обрывами с выходами скальных пород. Котловина суходольная, не имеет связи с подземными водоносными горизонтами, дно плоское, диаметром 40-50 м. Котловина Нагорная имеет примерно те же параметры, расположена у подножия хр. СевероВосточный. Борта котловины составлены склонами разной крутизны, юго-восточный борт обрывистый, со скальными выходами. Дно котловины плоское, диаметром 70-80 м. На дне расположено неглубокое оз. Провальное с диаметром зеркала 20-25 м. По системам тектонических трещин сток озера происходит в урезе воды залива Мухор в бухте Щучья, где расположены низкодебитные ключи. Котловина Внутренняя уступает предыдущим по размерам. Она округлых очертаний, диаметром около 80 м, пологовогнутая, с плоским дном. Северный борт осложнен небольшими скальными выходами. Борта невысокие - до 10-15 м. Различна и 
рекреационно-эстетическая значимость котловин. Котловина Глубокая примечательна своей угрюмостью, изолированным положением. Котловина Нагорная открытая, с перспективой для обзора и достаточным освещением. Котловина Внутренняя небольшая, правильных очертаний, с хорошим освещением.

Среди других отрицательных форм рельефа высокое рекреационное значение имеют седловины. Они могут быть использованы как площадки для проведения стационарных наблюдений. Большинство их обеспечено для этого удобной морфологией (ровные, слабо пересеченные, безлесные) и достаточной для приема больших групп туристов и рекреантов площадью (более $1000 \mathrm{M}^{2}$ ). Более половины седловин обладает низкой геоморфологической опасностью, высокой пейзажной привлекательностью и эстетической ценностью ландшафта. Почти $80 \%$ седловин легко доступно даже для слаборазвитых в физическом отношении туристов. Они могут быть неплохой заменой останцовым вершинам для проведения обзорных наблюдений и ориентирования на местности. Так, около $40 \%$ седловин имеет превышение над уровнем залива Мухор более 100 м, достаточно широкий (более $180^{\circ}$ ) угол обзора и высокую дальность - до 20 км. А с учетом низкой геоморфологической опасности и площади, достаточной для приема больших групп туристов (что редко встречается на останцовых вершинах), рекреационная значимость седловин возрастает. Седловины богаты растительностью, вызывающей большой геоботанический интерес.

Примечательны и другие отрицательные формы рельефа: пади и лога. Их морфометрические параметры позволяют проводить туристические маршруты различной сложности и назначения. Пади Широкая, Лесистая, Фермерская легко доступные, с ровной поверхностью, могут быть использованы для туристов со слабой физической подготовкой. Пади Приразломная, Солнечная, Амфитеатры требуют физической выносливости и технической подготовки в связи с их пересеченной поверхностью, крутыми склонами, значительными подъемами, выходами кристаллических пород, которые формируют небольшие уступы и обрывы. Это же следует отнести к логам Ущелье, Крутой и Степной. Для посещения логов Обрывистый и Ласточкин провал требуются специальная физическая подготовка и развернутый инструктаж, поскольку здесь изобилуют обрывистые стенки, нависающие карнизы горных пород, возможны обвалы и осыпи, требуются значительные подъемы, преодоление сложных препятствий в виде расщелин, неустойчивых склонов, вертикальных или нависающих уступов. В целом следует сказать, что пейзажная привлекательность падей и логов высокая, они обладают многочисленными эстетически ценными и научно-познавательными элементами рельефа и ландшафта.

Высоким туристическим потенциалом обладают участки рельефа, где развиты серии узких, линейно вытянутых невысоких гребней и грив, которые разделены такими же линейно вытянутыми параллельными понижениями (гребнистозападинные системы). Высоты гребней либо примерно одинаковые, либо заметно снижаются по направлению от вершин хребта Южный к побережью залива Мухор. В последнем случае гребнисто-западинные системы представлены в виде своеобразных каскадов с мелкими уступами и террасовидными площадками. 
На увале Тойнак и полуострове Халуринский они создают ансамбли экзотических и изолированных живописных западин и отвесов, которые используются неорганизованными туристами в качестве мест для стоянок. Здесь на ограниченном пространстве можно разместить большое количество туристических лагерей, при этом в каждом из них создается иллюзия изолированности, одиночества и покоя, что чрезвычайно ценится отдыхающими. У подножья хребта Южный и на массиве Юго-Западный серии гребней и понижений представлены каскадами. Гребни здесь значительно ниже, не изолируют понижения в должной мере; однако их значительно больше и расположены они чаще. Такой геоморфологический ландшафт удобен для полустационарного размещения больших групп рекреантов.

На периферии полигона располагаются долины небольших рек Кучелга, Харга, ручья Кулуринский. В долине ручья Кулуринский речные террасы и пойма имеют ограниченный рекреационный потенциал, поскольку по ним проходит улучшенная грунтовая дорога Еланцы - Зама. Ширина дороги - 6 м, с дорожными откосами - 10 м, с придорожными кюветами - 20 м. В нескольких местах кюветы перехватывают сток ручья в период редких обильных дождей. В результате развивается дорожная эрозия, которая незначительно размывает дорогу, но сильно изменяет ландшафты в ее окрестностях. Сказанное относится и ко дну долин рек Харга и Кучелга. По ним также проложены дороги, которые сильно нарушают слабоустойчивые к антропогенному воздействию ландшафты поймы. Дороги здесь не отсыпанные, поэтому податливые почвы поймы легко разрушаются, дерновина сносится, происходит заболачивание местности. В местах, где дороги проходят по террасам, ситуация несколько лучше, т. к. хорошо сдренированные грунты выдерживают нагрузки.

Рекреационно-геоморфологическое значение террас состоит не только в возможности прокладывать по ним дороги и туристические тропы. Они могут использоваться для строительства полустационарных объектов, размещения больших групп отдыхающих. Для террасы р. Харги ситуация осложняется тем, что здесь расположены остатки древних культово-обрядовых сооружений, имеющих историко-культурную ценность. Пойма рек, включающая заливные луга и русла, используется местным населением для выпаса скота. В пойме р. Кучелги луга принадлежат ферме Кулура. Пойма р. Харги не арендуется местными жителями и здесь возможна организация туристических экскурсий. Особенно привлекательна пойма в совокупности с покрывающей ее растительностью (заливные луга, болота, кустарники, ерниковые заросли).

Одними из главных составляющих туристического потенциала рельефа полигона Кулура являются бухты и пляжи. Ширина бухт Университетская и Щучья в устьевой части достигает 200-220 м. Они закрыты от акватории Малого Моря далеко выдающимися мысами Тулхон и Халуринский. Бухта Университетская образована правильным распадком, спускающимся в нее с хребта СевероЗападный. Распадок начинается в пади Амфитеатр 1, прорезает хребет Центральный в логе Ущелье, в котловине между хребтами Центральный и Южный распадок расширяется до 300-350 м, а при пересечении хребта Южный сужается до 50-60 м. В месте максимального сужения располагаются выходы кристаллических 
горных пород - скал-утесов. У основания бухты распадок вновь расширяется до 100-120 м. До пересечения хребта Южный поверхность распадка слегка наклонная (до 5-6 $6^{0}$, в месте пересечения располагается небольшой $\left(10-12^{0}\right)$ уступ, далее до уреза воды поверхность почти ровная, с наклоном не более $2-3^{0}$. Полезная площадь бухты с ровной поверхностью составляет около $8000 \mathrm{~m}^{2}$. Ярко выраженного русла в распадке нет. Воды стекают по нему либо в виде поверхностного стока, либо в период дождей и снеготаяния по небольшой пологой ложбине у правого борта.

Возле основания бухты Университетская берег залива покрыт болотной растительностью, в центральной части - луговой. По периметру до выхода к устью бухты располагаются пляжи: ширина - 2-3 м, протяженность - 40-60 м. В месте перехода от заросшего луговой растительностью берега к пляжам расположены самые благоприятные для отдыха участки. Здесь берег сложен песком и гравием. Далее до выхода на скалистые мысы располагаются галечные пляжи. Их структура осложняется обваливающимися с крутых скалистых склонов щебнем и глыбами. Породы высокотрещиноватые, имеют листоватую, чешуйчатую структуру, обломки дают много мелкой крошки с острыми краями. Дно бухты заросло водорослями и покрыто слоем ила (до 15-20 см). Глубина не превышает 2 м, только под обрывистым левым берегом глубина увеличивается до 2,5 м. Наиболее удобен для рекреации левый берег. Ширина песчаной отмели здесь максимальна (4 м), длина пригодного участка - 50-60 м. В отложениях дна большую долю составляет песчаный материал. К пляжу подходит склон средней крутизны, покрытый степной растительностью, на котором может расположиться большое число туристов. Пляж и склон имеют южную экспозицию. Правый берег бухты менее комфортен. Примыкающий к нему склон крутой, зарос лиственницами, над пляжем имеется обрыв высотой до 2 м. Пляж узкий, с большим количеством глыб. Длина пригодного для рекреации участка составляет не более 25 м.

Бухта Щучья образована в котловине между хребтами Центральный и Южный. Ее основание практически полностью изолированное. Подходящая к нему небольшая падь имеет значительный уклон поверхности (до $5-7^{0}$ ), на которой отмечаются выходы кристаллических пород с небольшими обрывами и западинами. Борта бухты образованы крутыми (правый) или практически отвесными скалистыми (левый) склонами. Ровная площадка имеется только у самого берега в основании бухты. Площадь не достигает $1000 \mathrm{~m}^{2}$ и значительная часть ее заболочена. Пляжи отсутствуют. Дно бухты от самого берега покрыто водной растительностью. Глубина в акватории не более 1,5 м. Вдоль бухты у подножия хребта Центральный протягивается узкая ровная полоска берега шириной до 2 м, по которой можно достичь увала Тойнак.

Элементами рельефа, обладающими высокой эколого-туристической значимостью, являются пляжные зоны. На полигоне их четыре. Наиболее привлекательным является Лазурный берег. Это открытое солнечное и теплое побережье с перспективными видами на Малое Море, его острова, мысы и бухты. Много места для пляжного отдыха и купания. Осложняется положение Лазурного берега примыкающими к нему невысокими крутыми уступами, в некоторых местах 
с обрывами до 4-5 м. Высоким потенциалом обладают и Одинокие пляжи. Здесь нет того комфорта, который присущ Лазурному берегу, поскольку берега крутые, пляжи узкие, преимущественно галечные и галечно-щебнистые. Но это восполняется хорошей изолированностью, уединенностью местности, наличием очень маленьких уютных бухт, в которых может поместиться не более 2-3 человек. Значительно меньшим рекреационным потенциалом характеризуются Солнечный и Каменистый берега. Пляжи здесь очень узкие, состоят из галечно-щебнистого и галечно-глыбового материала, дно каменистое, с резким увеличением глубины, берег представлен крутыми уступами, обрывами, бухт мало, они мелкие. Однако эти берега имеют выгодную юго-западную экспозицию, что обеспечивает хорошее прогревание поверхности в часы наибольшей солнечной активности.

\section{Рельеф как источник риска природопользования}

Для оценки риска природопользования на полигоне Кулура в результате развития опасных геолого-геоморфологических процессов использовано два основных критерия: 1) степень антропогенной нарушенности ландшафтов, 2) степень геоморфологической опасности.

На полигоне развито фермерское хозяйство и частично - организованный туризм. Приезжими туристами поддерживаются и традиционные промыслы в виде сбора лекарственных растений и рыболовства. Фермерское хозяйство представлено фермой Кулура, где разводят крупный рогатый скот, для чего арендуют заливные луга в пойме р. Кучелги, на которых заготавливают сено. Летний выпас осуществляется по окрестным падям и в долине р. Харги. На ферме ведется комплексное хозяйство, в котором большую долю занимает рыболовство и хлебопечение. Сбыт продукции осуществляется в прилегающие населенные пункты и среди туристов. Хозяйство фермы низкорентабельное. Пастбища низкопродуктивные, запасов сена с пойменных лугов хватает лишь на ограниченное поголовье, во время выпаса скот постоянно подвергается гонению со стороны туристов. Рыбная ловля также стала низкорентабельной из-за невысокого спроса на рыбу и жесткой конкуренции. Определенный денежный доход приносит продажа хлеба в деревни и туристам.

Частично организованный туризм - это основная форма хозяйственной деятельности на полигоне Кулура, а также негативный фактор воздействия на ландшафты. В летние месяцы все побережье занято туристическими лагерями, в основном спонтанными. Массовый характер это приобрело в последние 15-20 лет. Подавляющее число приезжих - неорганизованные группы отдыхающих, которые разбивают палаточные лагеря непосредственно на побережье и в некотором удалении от него. Меньшую часть составляют организованные базы отдыха, которые для своего размещения используют стационарные деревянные конструкции (домики) без фундамента. Период наиболее массового туризма и рекреации приходится на июль-август. Зимой на полигоне можно встретить любителей подледного лова рыбы. Однако это одиночные стоянки.

Основной вклад в антропогенную нарушенность земель на полигоне Кулура вносит деятельность туристов и рекреантов. Нами составлена карта антропогенной нарушенности полигона (рис. 6). 


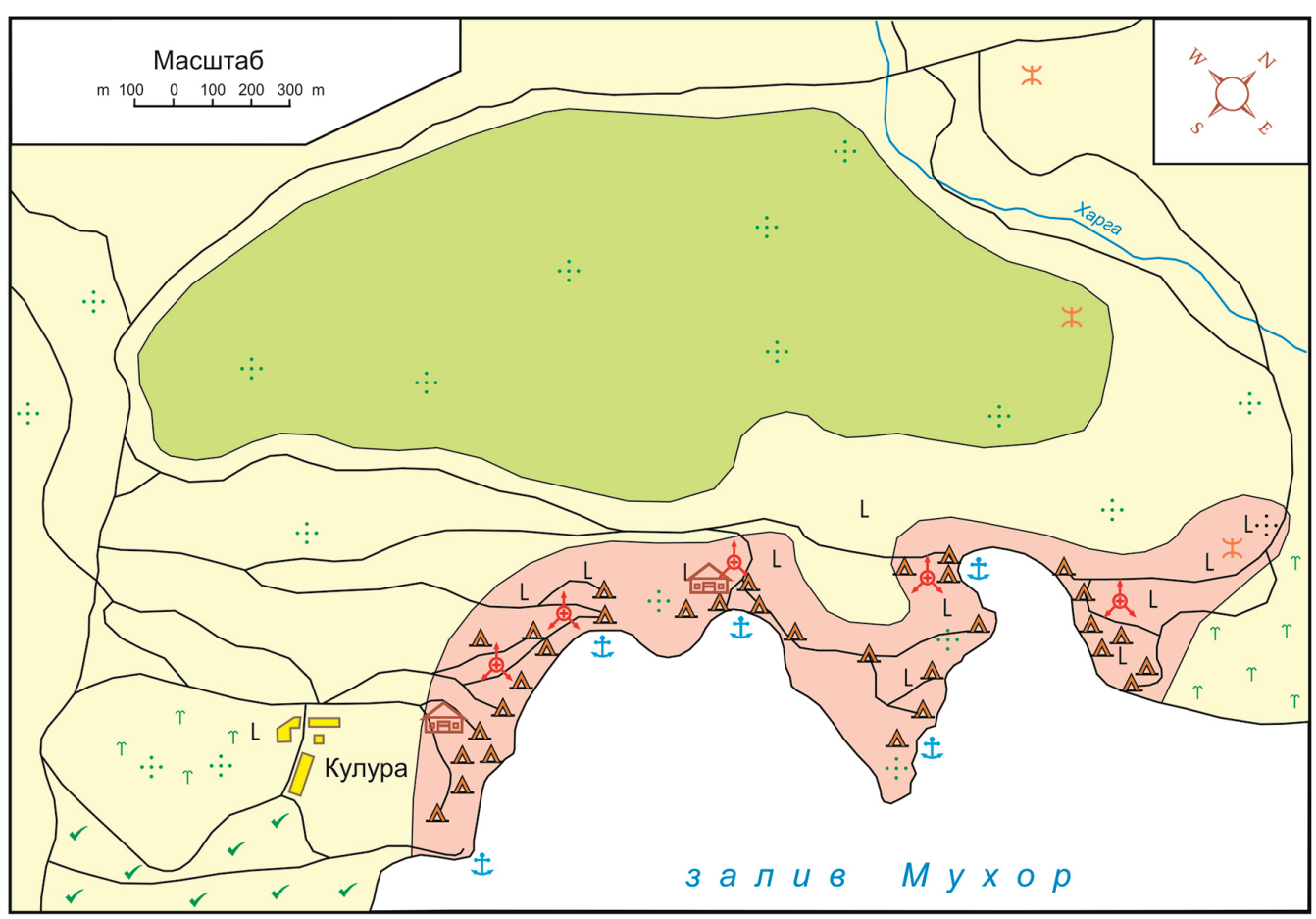

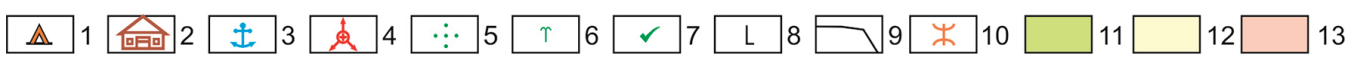

Puc. 6. Антропогенная нарушенность полигона Кулура. Виды нарушений: 1 - туристические стоянки, 2 - стационарные турбазы; 3 - места частого причаливания лодок, 4 мусорные свалки, 5 - места сбора дикоросов, 6 - пастбища, 7 - сенокосы, 8 - вырубки, 9 - дороги. 10 - археологические и историко-культурные памятники. Степень нарушенности: 10 - условно ненарушенные земли, 11 - умеренная, 12 - высокая

На ней выделены районы с высокой и умеренной нарушенностью и условно ненарушенные. Высоко нарушенными считались земли с наиболее густой сетью дорог и троп, где расположены туристические базы и временные стоянки, проводятся земляные работы по их обустройству, вырубка деревьев, формируются спонтанные мусорные свалки и т.д. Умеренно нарушенными считались земли, на которых развита разреженная сеть коммуникаций (тропы, дороги), расположены сельскохозяйственные угодья (пастбища, сенокосы), ферма Кулура. Условно ненарушенными считались земли, на которых практически отсутствуют следы антропогенной деятельности (за исключением временных троп, одиночных закопов и канав, сделанных в научных и учебных целях).

Высокая антропогенная нарушенность ландшафтов характерна для вдоль береговой полосы залива Мухор. Разрушаются как абразионные берега на мысах, так и аккумулятивные в бухтах. На мысах характерными видами нарушений являются каменные навалы и развалы, вдольбереговые и ведущие к берегу тропинки, которые способствуют развитию абразионных и эрозионных процессов. В бухтах характерными видами нарушений являются продуктовые и туалетные ямы. Для всего побережья характерны мусорные свалки, хаотичные тропы, вырубки 
редкостойных лиственничников. Указанные виды нарушений приводят не только к снижению туристической значимости территории, потере ее привлекательности для рекреации, но и активизируют опасные геолого-геоморфологические процессы. Усиливается абразионная деятельность, разрушаются пляжные зоны, в бухтах происходит заболачивание и заиление побережья, формируется кочкарнозападинная, неэстетичная и не пригодная для отдыха местность. Вдоль дорог и троп активизируется дорожная эрозия, происходит размыв грунтов, а также образование оврагов. На крутых склонах и в местах их подрезки дорогами образуются осыпи и провалы, разрушающие дорожную колею, активизируется термоэрозия. В результате нарушения почвенного слоя в бухтах активизируются площадная эрозия и поверхностный смыв. По причине продолжительных дождей образуются селевые потоки.

Умеренно нарушенные земли занимают большую часть полигона, где проложены немногочисленные автомобильные дороги и сеть пешеходных троп. Причем за последние 10-12 лет степень нарушенности полигона дорогами и тропами возросла примерно в 3 раза. Умеренно нарушенными считались и сельскохозяйственные земли фермы Кулура. Большая площадь поймы р. Кучелги занята сенокосными угодьями. В пойме р. Харги и вдоль побережья бухт осуществляется выпас крупного рогатого скота. Степень развития антропогенно спровоцированных факторов геоморфологической опасности в зонах умеренной антропогенной нарушенности намного ниже.

Условно ненарушенной считалась территория в центральной части полигона Кулура. Здесь практически отсутствуют следы активной антропогенной деятельности, за исключением некоторых временных дорог и троп, старых мелких вырубок. Факторами опасности выступают типичные для данной территории геологогеоморфологические процессы (табл. 1).

Для оценки геоморфологической опасности следует выбрать параметры, ответственные за формирование современного рельефа. Полигон располагается в зоне влияния геодинамически активного Приморского разлома, на западном плече Байкальского рифта в его центральной части. Приморский разлом формирует северо-западный борт впадины Малого Моря и Кучелго-Таловской депрессии, которая в региональном геолого-структурном плане образует ЧернорудскоБугульдейский грабен. Разлом активен на протяжении позднего кайнозоя и в современный период. Тектонические движения сформировали на полигоне контрастный (клавишный) рельеф, типичный для континентальных рифтов. Современный структурный рисунок территории полигона (сетка линеаментов) обеспечивает формирование основных черт морфологии рельефа. Экзогенные процессы, такие как эрозия, карст, абразия, заболачивание, усложняют структуру рельефа, разнообразят облик ландшафта.

В качестве критериев геоморфологической опасности выделено два морфометрических показателя: 1) плотность линеаментов — потенциальная способность горных пород и массивов быть подверженными разрушению геоморфологическими процессами, 2) градиент гипсометрических высот - потенциальная гравитационная энергия рельефообразующих процессов. 
С. Б. Кузьмин. Опасные геоморфологические процессы на локальном полигоне Байкальской природной территории

Таблииа 1

Опасные геолого-геоморфологические процессы на полигоне Кулура

\begin{tabular}{|c|c|c|c|}
\hline Процессы & Тип & Форма рельефа & Источник опасности \\
\hline $\begin{array}{l}\text { Тектонический } \\
\text { крип }\end{array}$ & фронтальный & уступы & $\begin{array}{l}\text { тектонические движения по зонам } \\
\text { разломов }\end{array}$ \\
\hline Термокарст & точечный & $\begin{array}{l}\text { низкая и высокая } \\
\text { пойма }\end{array}$ & $\begin{array}{l}\text { термогидрогенные изменения, } \\
\text { наледеобразование, режеляция } \\
\text { грунтов }\end{array}$ \\
\hline Обвалы, осыпи & фронтальный & $\begin{array}{l}\text { крутые склоны, } \\
\text { уступы, в т. ч. } \\
\text { абразионные } \\
\end{array}$ & $\begin{array}{l}\text { гравитационные процессы, } \\
\text { трещинообразование, } \\
\text { сейсмические потрясения } \\
\end{array}$ \\
\hline $\begin{array}{l}\text { Дефлюкция } \\
\text { и криогенное } \\
\text { сплывание } \\
\end{array}$ & площадной & $\begin{array}{l}\text { крутые склоны } \\
\text { и склоны средней } \\
\text { крутизны }\end{array}$ & $\begin{array}{l}\text { термогидрогенные изменения, } \\
\text { режеляция грунтов, } \\
\text { гравитационные процессы }\end{array}$ \\
\hline $\begin{array}{l}\text { Плоскостной } \\
\text { смыв }\end{array}$ & площадной & $\begin{array}{l}\text { пологие склоны } \\
\text { и склоны средней } \\
\text { крутизны }\end{array}$ & $\begin{array}{l}\text { обильные атмосферные осадки, } \\
\text { антропогенное разрушение почв и } \\
\text { грунтов }\end{array}$ \\
\hline $\begin{array}{l}\text { Овражная } \\
\text { эрозия }\end{array}$ & линейный & пологие склоны & $\begin{array}{l}\text { обильные атмосферные осадки, } \\
\text { антропогенное разрушение почв и } \\
\text { грунтов }\end{array}$ \\
\hline Абразия & фронтальный & $\begin{array}{l}\text { абразионные } \\
\text { уступы }\end{array}$ & волноприбойная деятельность \\
\hline $\begin{array}{l}\text { Дефляция, } \\
\text { корразия }\end{array}$ & площадной & $\begin{array}{l}\text { уступы, в т. ч. } \\
\text { абразионные }\end{array}$ & денудационная деятельность ветра \\
\hline $\begin{array}{l}\text { Глубинная и } \\
\text { боковая эрозия }\end{array}$ & линейный & $\begin{array}{l}\text { русла рек, лога, } \\
\text { долины времен- } \\
\text { ных водотоков } \\
\end{array}$ & $\begin{array}{l}\text { обильные атмосферные осадки, } \\
\text { гравитационный потенциал рельефа }\end{array}$ \\
\hline Карст & точечный & $\begin{array}{l}\text { крутые склоны } \\
\text { и уступы } \\
\end{array}$ & $\begin{array}{l}\text { наличие карстующихся пород, доста- } \\
\text { точное атмосферное увлажнение }\end{array}$ \\
\hline $\begin{array}{l}\text { Торфообразо- } \\
\text { вание, забола- } \\
\text { чивание }\end{array}$ & площадной & $\begin{array}{l}\text { низкая и высокая } \\
\text { пойма, устьевые } \\
\text { части распадков }\end{array}$ & $\begin{array}{l}\text { изменение уровня байкала и подпор } \\
\text { береговых валов, прогибание мелких } \\
\text { впадин, климатические условия }\end{array}$ \\
\hline $\begin{array}{l}\text { Формирование } \\
\text { дорог и троп }\end{array}$ & линейный & $\begin{array}{l}\text { высокая пойма, } \\
\text { террасы }\end{array}$ & $\begin{array}{l}\text { антропогенная хозяйственная } \\
\text { и рекреационная деятельность }\end{array}$ \\
\hline
\end{tabular}

Земная кора разбита на блоки различной тектонической активности. Границы блоков представляют собой геодинамически активные зоны, часто разломы с аномально напряженным динамическим состоянием, по которым происходят тектонические подвижки блоков. Это более разуплотненная и ослабленная масса горных пород по сравнению с блоками. Поэтому они являются наилучшими путями энергомассопереноса, фильтрации подземных вод, газовыделения, тепловых потоков и т. п. Геодинамические зоны проявляют себя на поверхности в виде линейно вытянутых форм рельефа, их границ, элементов гидрографической сети, зон почвенного и растительного контрастов и т. п. Поверхностные проявления в рельефе местности структурных элементов горных массивов называют линеаментами. Сетка линеаментов (потенциальных зон разломов и высокой трещиноватости горных пород) является показателем геологической структуры территории, а плотность 
линеаментов (их количество на определенной площади) - показателем степени раздробленности земной коры и устойчивости к денудации [Шульц, 1977; Кац и др., 1986].

Современная структурно-геоморфологическая позиция полигона Кулура оценена с помощью построения карты линеаментов (рис. 7). Для создания карты проведено дешифрирование аэрофотоснимков масштаба 1:10000 и 1:18000 и топокарт масштаба 1:25000, а также полевые исследования. На карте линеаменты подчеркивают уступы, гребни, крутые или обрывистые склоны, линейно-вытянутые трещиноватые зоны в горных породах, тектонические и структурные контакты, разломы, флексуры и т. п. Все эти геологогеоморфологические элементы способствуют активизации опасных морфогенетических процессов, обусловливают контрастность рельефа.

Большинство линеаментов имеет простирание, согласно с общим простиранием Приморского разлома, и образует Приморскую систему линеаментов. Также выделяются две другие системы: 1) Кулуринская, близкая к меридиональному простиранию, вычленяющая массив Юго-Западный, 2) Харгинская, близкая к широтному простиранию, формирующая правый борт долины р. Харги. Приморская система имеет простирание на $45^{\circ}$, Кулуринская $-0^{\circ}$, Харгинская $-80^{\circ}$. Три главные системы составляют $90 \%$ общего числа линеаментов на полигоне (табл. 2). Другие не формируют самостоятельных систем и подчинены главным, образуя дополнительные элементы инфраструктуры Приморского разлома. В целом все локальные линеаменты формируют неотектоническую микроструктуру полигона Кулура.

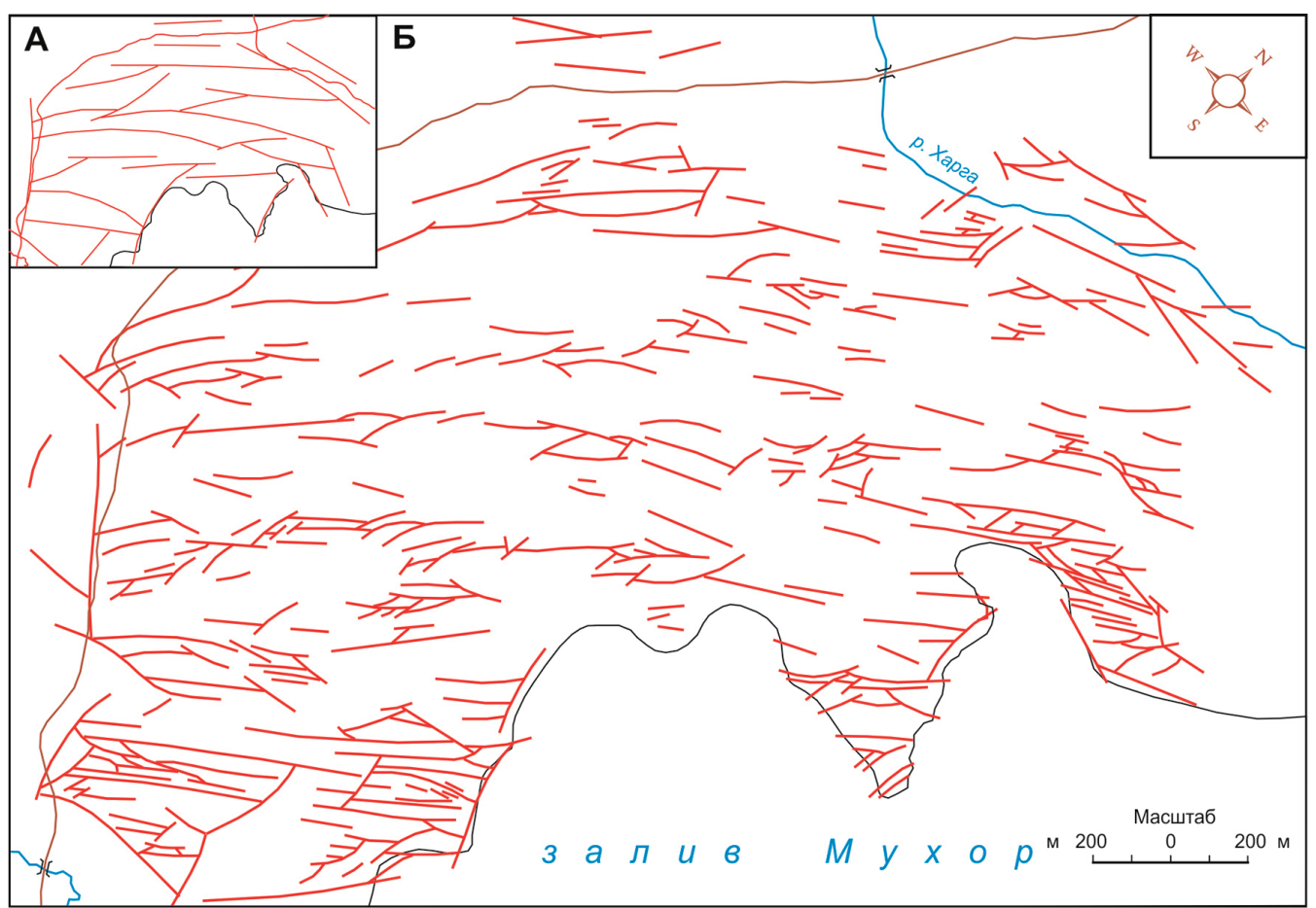

Pис. 7. Карта-схема линеаментов на полигоне Кулура: А — региональных, Б — локальных 
C. Б. Кузьмин. Опасные геоморфологические процессы на локальном полигоне Байкальской природной территории

Таблииа 2

Процентное соотношение числа линеаментов на полигоне Кулура

\begin{tabular}{|l|l|}
\hline Наименование систем линеаментов & Процент от общего числа линеаментов \\
\hline Приморская & 61 \\
\hline Кулуринская & 19 \\
\hline Харгинская & 10 \\
\hline Прочие & 10 \\
\hline
\end{tabular}

Локальные линеаменты на полигоне группируются в динамически и пространственно связанные структуры - линеаментные системы. Структурный рисунок локальных линеаментов позволяет выделить линеаментные системы и вычленяемые ими блоки. На рис. 7А выделяется главное Приморское северо-восточное направление групп линеаментов, субширотная Харгинская система и субмеридиональная Кулуринская система. На юго-востоке полигона Харгинская и Кулуринская системы образуют зону сопряжения и вычленяют бухту Щучья и увал Тойнак. Такая же картина наблюдается в районе массива Юго-Западный. В совокупности все три указанные системы формируют неотектоническую макроструктуру полигона Кулура. На основе карты линеаментов составлена карта их плотности (рис. 8).

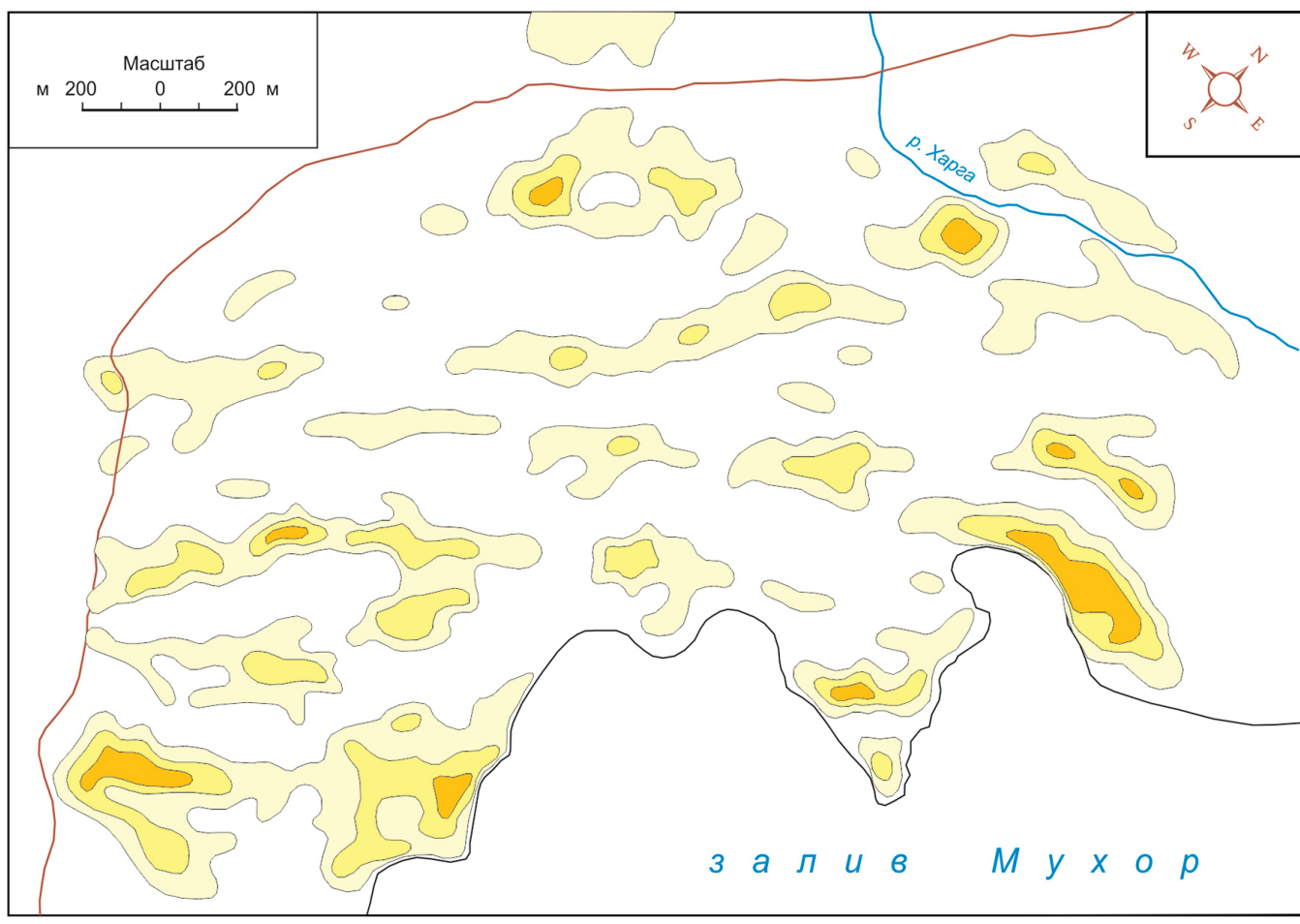

1

2

3

4

Puc. 8. Плотность линеаментов на полигоне Кулура (шт./га): $1-0-2 ; 2-2-4 ; 3-4-6$; 4 - более 6 . 
Плотность линеаментов - это их количество на фиксированной площади [Шерман, 1977]. Для подсчета плотности используется квадратная палетка, размер которой определяется по формуле:

$$
\mathrm{s}=2 \mathrm{~S} / \mathrm{n}_{\text {sum }} \text {, }
$$

где $\mathrm{S}$ - площадь района, $\mathrm{n}_{\text {sum }}$ - число наблюдений за параметром [Крамер, 1975]. Использован метод расчета по жесткой (фиксированной) сетке-матрице - палетке. Шаг измерений и расстояние между измерительными профилями принимались равными длине стороны палетки, что обеспечивало полное перекрытие измеряемого параметра по площади. Минимальный шаг между изолиниями определялся по формуле:

$\mathrm{h}=\left(\mathrm{X}_{\max }-\mathrm{X}_{\min }\right) /(1+3.3 \log \gamma)$,

где $\mathrm{X}_{\max }-\mathrm{X}_{\min }$ - максимальное и минимальное значение параметра плотности линеаментов, $\gamma$ - количество измерений параметра.

На основании проведенных расчетов площадь палетки для подсчета плотности линеаментов на полигоне Кулура принята равной 1 га, шаг измерений -100 м, шаг между изолиниями - 2 шт./1 га. В дальнейшем определялась аномальная величина плотности линеаментов, которая должна была оконтурить области, несущие потенциальную геоморфологическую опасность. Для этого использовалась формула:

$$
X_{a}=X_{n}+2 \sigma
$$

где $\mathrm{X}_{\mathrm{a}}$ - аномальная величина плотности линеаментов, $\mathrm{X}_{\mathrm{n}}$ - среднее значение плотности разломов на полигоне Кулура, которое определялось по формуле:

$$
\mathrm{X}_{\mathrm{n}}=\Sigma \mathrm{X}_{\mathrm{i}} / \gamma \text {. }
$$

Величина б показывает среднюю квадратичную ошибку по выборке значений плотности линеаментов:

$$
\sigma=\mathrm{e} / \gamma^{1 / 2}
$$

где е - среднее квадратичное отклонение, рассчитанное по формуле:

$$
\mathrm{e}^{2}=1 /(\gamma-1)\left(\Omega-\Sigma \mathrm{X}_{\mathrm{i}}^{2} / \gamma\right) \text {, }
$$

где $\Omega$ - сумма наблюдений плотности линеаментов [Голиков и др., 1986].

Аномальная плотность линеаментов $X_{a}$ редко совпадает с шагом изолиний, поэтому осуществляется округление ее значений в большую сторону до ближайшего шага изолиний. Для полигона границей, выделяющей аномальные значения плотности линеаментов, принята изолиния со значением 2.

Вторым критерием для определения геоморфологической опасности является градиент гипсометрических высот рельефа. Градиент высот рельефа - это изменение абсолютных или относительных высот рельефа на некоторой фиксированной площади (окно палетки), отражающее потенциальную геодинамическую энергию рельефа, обусловленную естественной кривизной земной поверхности и силами гравитации. Этот морфометрический показатель с успехом может быть использован для горных территорий с контрастным рельефом и активным развитием геодинамических процессов [Ласточкин, 1975; Леви, 1981]. Морфометрический анализ рельефа (густота вертикального и горизонтального расчленения рельефа, крутизна и экспозиция склонов) для оценки геоморфологической опасности и риска рекреационной деятельности имеется в литературе на примере горных территорий Предкавказья — район г. Сочи [Анисимов, Заседателев, 1993]. 


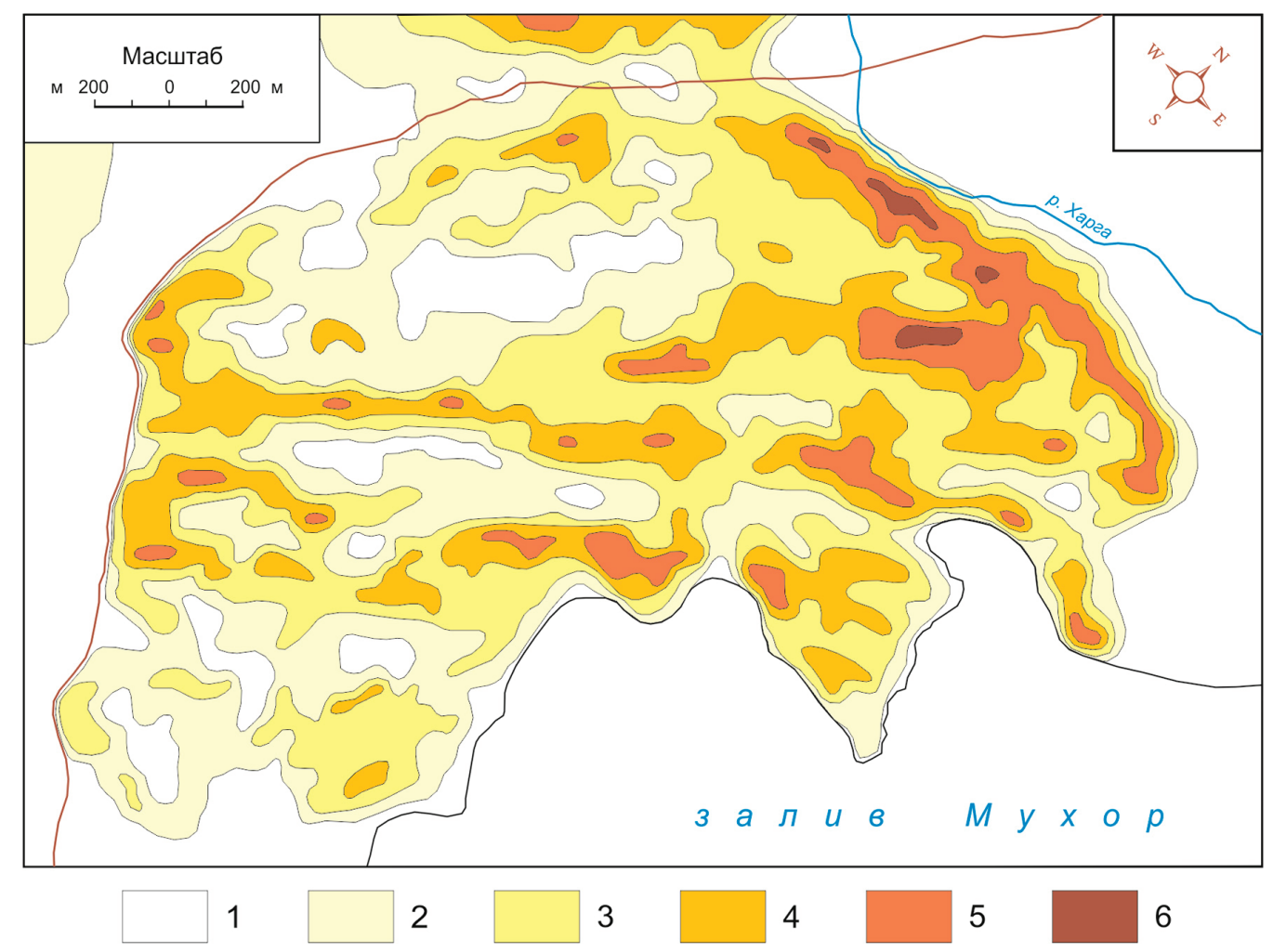

Рис. 9. Градиенты высот на полигоне Кулура (м/100 м): $1-0-10 ; 2-10-20 ; 3-20-30$; $4-30-40 ; 5-40-50 ; 6$ - более 50

Для полигона Кулура составлена также карта градиентов высот рельефа (рис. 9) на основе разработанных нами морфометрических методов. При этом анализировались гипсометрические кривые (изолинии) рельефа. В этом случае для измерения значений градиентов высот и составления соответствующей карты эффективнее использовать не жесткую (фиксированную) сетку, а метод скользящего профилирования [Богацкий и др., 1977]. Для него характерно использование круглой палетки, которая позволяет избежать искажения информации при ее вращении. В остальном процедура расчета параметров, аномальных значений и составления карты аналогична описанной ранее для плотности линеаментов. Отметим, что для карты градиентов высот рельефа рассчитанный диаметр палетки равен 100 м, шаг измерений и расстояние между измерительными профилями - 50 м, шаг между изолиниями - 10/100 м, аномальное значение градиента высот рельефа - 30/100 м.

Для карты геоморфологической опасности проводилось наложение (суперпозиция) выделенных областей с аномальными и фоновыми значениями плотности линеаментов и градиента высот рельефа. Этот методический прием позволил выделить три генерации областей: 1) с фоновыми значениями обоих параметров геоморфологическая опасность отсутствует; 2) с аномальным значением одного параметра - умеренная опасность; 3) с аномальными значениями обоих параметров - высокая опасность. Там, где потенциальная гравитационная энергия 
рельефа крайне мала (дно долин, прибрежные районы залива Мухор), опасность могутпредставлять другие геоморфологическиепроцессы. Поэтому к типу областей с умеренной геоморфологической опасностью отнесены также пойменно-долинные комплексы, устья и прибрежные низины, где велика вероятность развития таких опасных процессов, как плановые деформации русел рек, размыв берегов, низкой и высокой поймы, дефляция, эрозия, заболачивание и т. д. (рис. 10).

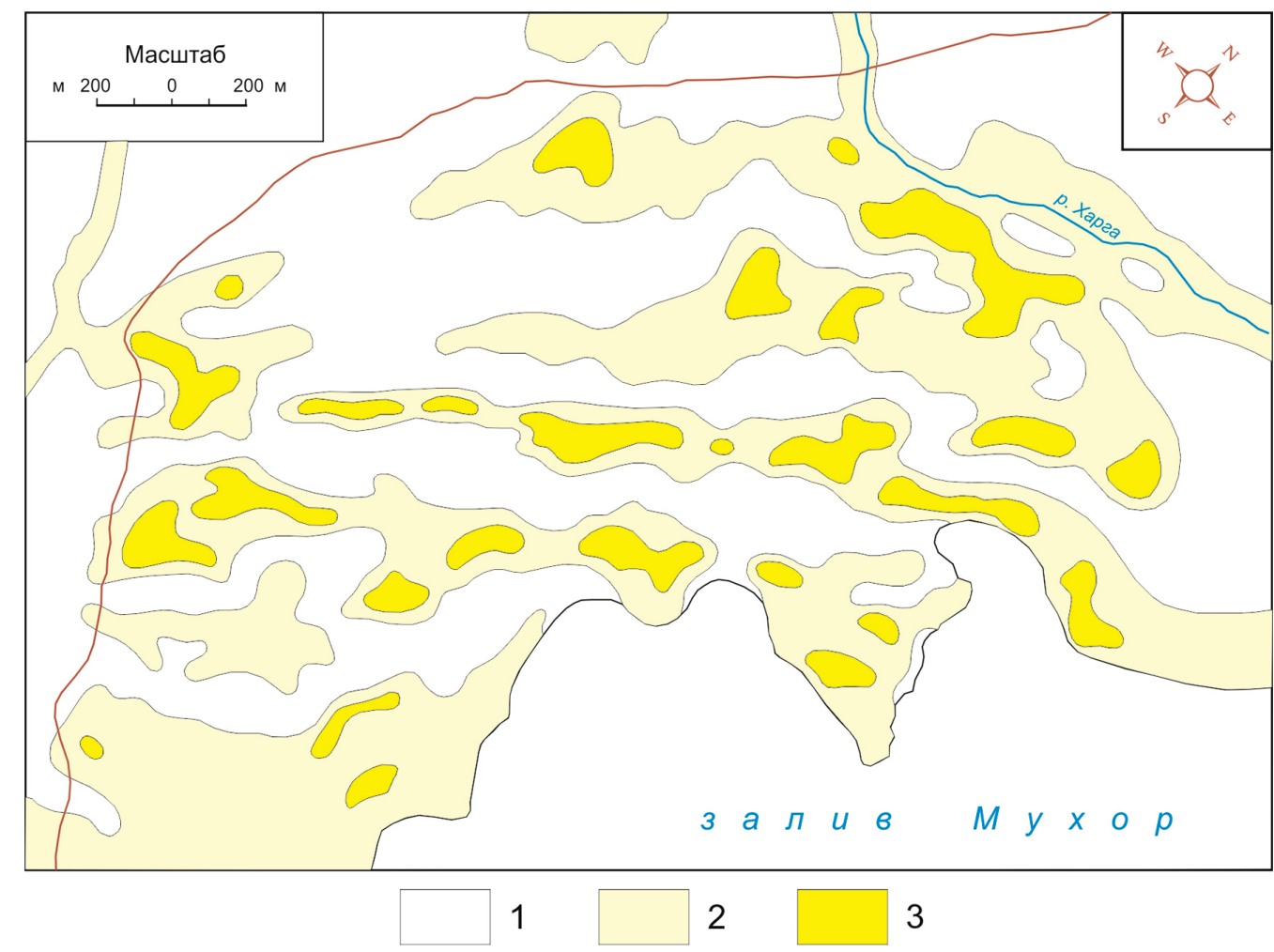

Рuc. 10. Геоморфологическая опасность на полигоне Кулура: 1 - условно отсутствует; 2 - умеренная; 3 - высокая

Для большей части полигона характерна умеренная или отсутствующая геоморфологическая опасность. Она обусловлена в основном естественным строением рельефа территории и геоморфологическими процессами. Условно отсутствует геоморфологическая опасность в долинах рек на террасах, на пологих склонах, в широких пологонаклонных падях, в межгорных понижениях, седловинах, на берегах бухт. Умеренная геоморфологическая опасность характерна для пойменнорусловых комплексов речных долин, склонов средней крутизны, падей и логов, абразионных берегов, котловин. Высокая геоморфологическая опасность наблюдается на крутых склонах, уступах, эскарпах, останцовых возвышенностях, узких гребнях, местах развития суффозионных и карстово-провальных форм рельефа. 
Риск туристско-рекреационной деятельности (природопользования) на полигоне Кулура складывается из двух показателей: 1) геоморфологической опасности и 2) антропогенной нарушенности. Совместный анализ карты обоих показателей позволяет в каждом конкретном случае судить о степени риска на тех или иных участках полигона (рис. 11).

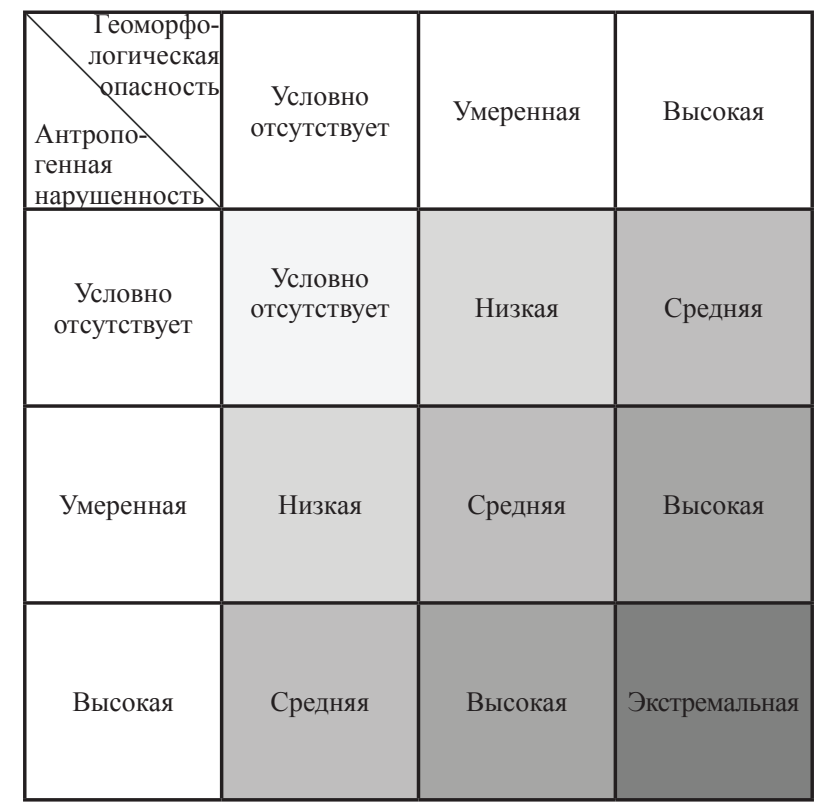

Puc. 11. Оценка степени геоморфологического риска для организации туристскорекреационной деятельности на полигоне Кулура

Риск природопользования на полигоне возрастает в местах высокой антропогенной нарушенности, даже если геоморфологическая опасность в них может условно отсутствовать, - на побережье бухт и пляжей, вдоль дорог в широких падях и межгорных понижениях. Высок риск в пойменно-русловых комплексах, падях и логах, на склонах средней крутизны, вдоль абразионных берегов, подвергнутых интенсивному антропогенному прессингу. Опасные геологогеоморфологические процессы вероятны в местах с разрушением земель: заболоченных бухтах с нарушенным почвенным покровом, на крутых склонах и уступах, в районах развития карста и суффозии.

Для снижения риска на полигоне Кулура необходимо проведение комплекса превентивных мероприятий (табл. 3). Они схожи с мероприятиями для всего Приольхонья, но имеются и определенные различия.

Составленная карта геоморфологической опасности может лечь в основу планирования сети туристического использования территории Приольхонья на локальных полигонах. В обстановке низкой степени совершенства экономики туризма и рекреации в регионе риск природопользования возрастает. Поэтому отношение к опасностям в рельефе должно быть строгим, побудить разработчиков планов устойчивого развития Ольхонского района Иркутской области к учету факторов геоморфологической опасности при обеспечении безопасности туристско-рекреационной деятельности в регионе. 
Основные мероприятия по снижению степени геоморфологического риска туристско-рекреационной деятельности на полигоне Кулура

\begin{tabular}{|l|l|l|}
\hline \multicolumn{1}{|c|}{ Мероприятия } & \multicolumn{1}{|c|}{$\begin{array}{c}\text { Уровень } \\
\text { проведения }\end{array}$} & $\begin{array}{l}\text { Капитало- } \\
\text { вложения }\end{array}$ \\
\hline $\begin{array}{l}\text { Геоморфологическое районирование, оценка } \\
\text { опасных процессов и ресурсной значимости } \\
\text { рельефа }\end{array}$ & областной, ведомственный & высокие \\
\hline $\begin{array}{l}\text { Планирование и регулирование сети автодо- } \\
\text { рог и пешеходных троп }\end{array}$ & областной, муниципальный & высокие \\
\hline $\begin{array}{l}\text { Снижение доли неорганизованных туристов } \\
\text { Привлечение школьников, студентов, инициа- } \\
\text { тивной общественности, местного населения } \\
\text { к экологической реабилитации нарушенных } \\
\text { земель }\end{array}$ & областной, муниципальный & средние \\
\hline $\begin{array}{l}\text { Придание временного особого статуса муниципальный } \\
\text { высоконарушенным или высокоценным } \\
\text { ландшафтам (памятники природы, полигоны } \\
\text { для научных исследований и т. п.) }\end{array}$ & $\begin{array}{l}\text { областной, муниципальный, } \\
\text { ведомственный }\end{array}$ & средние \\
\hline $\begin{array}{l}\text { Создание на побережье залива Мухор } \\
\text { специализированных мест отдыха } \\
\text { и экологического туризма }\end{array}$ & $\begin{array}{l}\text { областной, муниципальный,, } \\
\text { ведомственный }\end{array}$ & высокие \\
\hline $\begin{array}{l}\text { Инструктаж по правилам поведения в живой } \\
\text { природе }\end{array}$ & $\begin{array}{l}\text { муниципальный, ведом- } \\
\text { ственный }\end{array}$ & низкие \\
\hline $\begin{array}{l}\text { Запрешение несанкцинированных земляных } \\
\text { работ, рекультивация земель }\end{array}$ & $\begin{array}{l}\text { муниципальный, ведом- } \\
\text { ственный }\end{array}$ & высокие \\
\hline $\begin{array}{l}\text { Поддержание и развитие традиционных } \\
\text { промыслов }\end{array}$ & муниципальный & средние \\
\hline $\begin{array}{l}\text { Определение оптимального количества } \\
\text { отдыхающих, которых способны выдержать } \\
\text { прибрежные ландшафты }\end{array}$ & ведомственный \\
\hline $\begin{array}{l}\text { Информационная и агитационная поддержка } \\
\text { общественных институтов, инициативных } \\
\text { групп }\end{array}$ & ведомственный & низкие \\
\hline
\end{tabular}

\section{Заключение}

Перечислим конкретные мероприятия для снижения риска рекреационнотуристической деятельности на полигоне Кулура в условиях активизации опасных геолого-геоморфологических процессов, приводящих к высокой нарушенности ландшафтов и экосистем. Они применимы не только для исследованного полигона, но и всей прибрежной территории Западного Прибайкалья в пределах Ольхонского района/Иркутской области, активно вовлеченной сегодня в рекреационно-туристическое хозяйственное освоение. Для обеспечения безопасности и защиты населения, экономики и территорий, оптимизации природноресурсного потенциала Приольхонья необходимо следующее: 1) привлечение 
в регион потенциальных инвесторов, туристических фирм и агентств с жестким административным контролем за их деятельностью; 2) использование опыта стран с развитым туристическим бизнесом - Швейцария, США, Франция и др.; 3) снижение доли неорганизованных туристов, упорядочивание и регламентация туристических потоков; 4) специальный инструктаж по правилам поведения в живой природе; 5) полное запрещение несанкционированных земляных работ, рекультивация нарушенных земель; 6) планирование и регулирование сети автодорог и пешеходных троп, оборудование мест для туристических баз и стоянок; 7) определение оптимального количества отдыхающих рекреантов и туристов, которых способны выдержать прибрежные ландшафты оз. Байкал и сама акватория водоема; 8) привлечение инвестиций в работы по экологической реабилитации ландшафтов со стороны заинтересованных организаций, фирм, предприятий; 9) информационная и агитационная поддержка со стороны общественных институтов, движений, инициативных групп; 10) принятие государственных, региональных и локальных (муниципальных) нормативных актов, регламентирующих деятельность как туристической отрасли, так и самих туристов, местного населения, органов контроля и аудита.

\section{Литература}

1. Анисимов В. И., Заседателев Ю. В. Морфометрический анализ горного рельефа для целей рекреации // Геоморфология. 1993. № 1. С. 51-57.

2. Антипцева Ю. О., Думит Ж. А. Морфометрический анализ рельефа с использованием ГИС-технологий при оценке рекреационного потенциала Лагонакского нагорья (Северо-Западный Кавказ) // Геоморфология. 2009. № 1. С. 45-50.

3. Богацкий В. В., Витязь В. И., Коллеганов Ю. М. Методические рекомендации по практическому осуществлению пространственно-статистических исследований. Новосибирск: Изд-во СНИИГГиМС, 1977. 48 с.

4. Бредихин А. В. Рекреационно-геоморфологические системы. М.; Смоленск: Ойкумена, 2010. 328 с.

5. Голиков А. П., Черванев И. Г., Трофимов А. М. Математические методы в географии. Харьков: Вища школа, 1986. 144 с.

6. Кац Я. Г., Полетаев А. И, Румянцева Э. Д. Основы линеаментной тектоники. М.: Недра, 1986. 140 с.

7. Крамер Г. Математические методы статистики. М.: Мир, 1975. 648 с.

8. Ласточкин С. В. Сравнительный анализ вертикальных тектонических движений в центральной части Байкальской рифтовой зоны и Забайкалье в связи с сейсмичностью // Геология и геофизика. 1975. № 9. С. 121-125.

9. Леви К. Г. Вертикальные движения земной коры в Байкальской рифтовой зоне // Проблемы разломной тектоники / под ред. Н. А. Логачева. Новосибирск: Наука, 1981. C. $142-170$.

10. Макаренко Е. П. Рекреационно-экологическая оценка рельефа как ведущего фактора развития туризма // Вестник Кемеровского госуниверситета. 2015. № 2. С. 115-120.

11. Минаев В. А., Фаддеев А. О. Оценка геоэкологических рисков. Моделирование безопасности туристско-рекреационных территорий. М.: Инфра-М, 2009. 334 с.

12. Фадеев А. О. Вопросы оценки геоэкологического риска и геоэкологической безопасности на рекреационных территориях // Проблемы безопасности и чрезвычайных ситуаций. 2008. № 6. С. 86-93. 
13. Шерман С. И. Физические закономерности развития разломов земной коры. Новосибирск: Наука, 1977. 101 с.

14. Шульц С. С. Методическое руководство по изучению планетарной трещиноватости и линеаментов. Л.: Изд-во ЛГУ, 1977. 136 с.

\section{HAZARDOUS GEOMORPHOLOGICAL PROCESSES AT THE LOCAL FIELD SITE OF THE BAIKAL NATURAL TERRITORY}

\section{S. B. Kuzmin}

\section{Sergey B. Kuzmin}

Dr. Sci. (Geogr.), Leading Researcher,

Sochava Institute of Geography SB RAS

1 Ulan-Batorskaya St., Irkutsk 664033, Russia

kuzmin@irigs.irk.ru

Abstract. The article analyzes the hazardous geomorphological processes at Kulura local field site, which is located in the Priolkhonye (Western Baikal region) within the Baikal natural territory. Due to the strict nature conservation status of the region tourism is the main typeof economic activity here. The article considers the geological and geomorphological conditions that contribute to the development of this type of economy. We have determined the degree of anthropogenic disturbance at the local field site, carried out the risk assessment of nature management as a result of activation of hazardous geomorphological processes, and proposed the risk reduction measures.

Keywords: hazardous geomorphological processes; environmental risk; the Priolkhonye; the Baikal natural territory. 